\title{
Character Analysis Through Politeness in A Good Man Is Hard to Find by Flannery O'Connor
}

\author{
Le Thi Bich Thuan (Corresponding author) \\ University of Social Sciences \& Humanities-Vietnam National University, Ho Chi Minh City, Vietnam \\ E-mail: thuanftu2@gmail.com
}

Received: 16-12-2016

Published: 01-07-2017
Accepted: 13-03-2017

doi:10.7575/aiac.ijalel.v.6n.4p.218
Advance Access Published: April 2017

URL: http://dx.doi.org/10.7575/aiac.ijalel.v.6n.4p.218

\begin{abstract}
This paper analyses the grandmother, the main character, in A Good Man Is Hard to Find, one of Flannery O'Connor's most famous short stories, in the light of pragmatic conversation, mainly including the theory of politeness. On the basis of the results, it has been concluded that the framework from pragmatics can provide effective tools for enhancing the understanding and interpretation of the character development in the study of literary works. This study is hopefully supposed to be beneficial for the specialists and analysts in the field of pragmatics and literature.
\end{abstract}

Keywords: conversation analysis theory; politeness theories; face theory; character analysis; A Good Man Is Hard to Find

\section{Introduction}

It is obvious that communication plays an essential role in the human-being's life. In fact, thanks to communicating, people can understand each other, get new knowledge, demonstrate their power over others and attain their personal goals. However, how to have a 'successful' conversation is a considerable concern because if we do not pay much attention to the way we interact, we will not fulfill our wishes. One of the tips to have a win-win dialogue is saving the other person's face.

Linguistic approaches to interaction have been deeply influenced by theories of face and politeness, and how face considerations shape our utterances in predictable ways. The notion of face and politeness help us much not only in judgments concerning the 'personalities' of people in real life but also in analyzing the conversational behaviors of characters in short stories. This is manifested in a number of literacy studies, namely, Simpson (1989), Rossen-Knill (1995), Buck (1997), Chikogu (2009), Chun (2010), Abbas 2013 and others. Based on the background above, the problem of the study is stated as follow: How pragmatics can assist the interpretation of literary texts? Therefore, the aim of this paper is demonstrating how we can use frameworks from pragmatics in general and politeness in particular to access the characters to answer the question: "How do readers of short stories form judgments concerning the 'personalities' of characters?"

In order to attain its goal, this paper analyses the conversations in the short story A Good Man Is Hard to Find (O’Connor, 1992) and attempts to study them from the angle of politeness analysis, which will be proved as an effective approach to the study of characters in literary works. The writer examines the manipulation of the grandmother's politeness by focusing on four prominent character traits: lordliness, talkativeness, selfishness, and hypocrisy which are inferable from her conversational behavior.

\subsection{Flannery O'Connor's A Good Man Is Hard To Find}

A Good Man Is Hard to Find shows Flannery O'Connor's deep anxiety about the values and the direction of the youth in 1950s. Contrary to the opinion of some critics that Flannery O'Connor's work is against moral, the researcher believes that she actually expresses the mightiness of God in a positive side. Most of her works are alike: the main characters have trouble in the extreme situation and at the end of the journey; they see the light of God, are illuminated and have their redemption. The story revolves around two characters: the 'enlightened' grandmother and the sinful Misfit, and they are all skillfully portrayed under Flannery O'Connor's pen. Through the conversation between the grandmother and The Misfit about a good man, the power of prayer, and the miracle of God, it is the grandmother's superficial Southern norms and self-absorption leading her inability to understand the religious non-believer Misfit or the fact that he could not be a good man. Moreover, in the dialogue with the grandmother, The Misfit experiences a deep internal struggle, revealing his doubt not only in religion but also in his own personality.

The story begins with the argument of the grandmother to go to Tennessee. Her son and her daughter-in-law do not listen to her and it is the grandchildren exposing the fact that even if they are not going where she wants, she will join them for fear of missing something. In the following day, the grandmother is the first person in the car and spends time entertaining and educating the children with stories, and her character is further developed and demonstrated by her 
stories and utterances. After stopping to have lunch at Red Sammy's where further discussions of The Misfit are engaged in, the family drives off again on the road and takes a detour according to the grandmother's instruction for visiting her old mansion. At the moment the grandmother suddenly realizes her mistake that the mansion is not in Georgia, but in Tennessee, the car accident occurs. Luckily, nobody is really injured. However, The Misfit and his henchmen are the first to come to help them. The Misfit orders his henchmen execute all the Bailey family and the grandmother is the last one to be killed. Seeing the death of the family members, the grandmother tries every chance to win The Misfit's pity and sympathy for her escape from death. Nevertheless, at the crucial moment the grandmother believes that her strategy works and reaches out her hand trying to touch The Misfit on his shoulder, he shoots her dead.

\subsection{Initial Observations On The Character Of The Grandmother}

The beginning of the story provides some brief but significant and meaningful descriptions of the grandmother: she is an old lady with outdated ideas and Southern manners: pays too much attention to her appearance - always wants to be sure that she will be seen as a lady - and tells stories about Southern gentlemen courting her. The grandmother appears as a manipulative and talkative person: constantly gives commands, exercises control, makes suggestions, and takes part in most of conversation of the story. Furthermore, she seems to be quite hypocritical in judging other people for not being like her. For instance, she is prone to stick herself to the saying 'People are certainly not nice like they used to be' and when the family's car passes a little black boy on the side of the road, her utterance 'Oh look at the cute pickaninny!' reveals her thought that she is better than others. Although she considers herself to be a good person: concerns for the well-being of her family, saves face of the interlocutors, always reminds the others to behave correctly, in fact she is hypocritical and full of herself. For example, at home, she tries everything in her power to get the family to go to Tennessee and in the car, she does not speak out that she wishes to visit the plantation house but tells lies about a secret panel in that house in order to make the children so curious that they stop the car there. She also tries her best to win The Misfit's sympathy and pity by using politeness strategies. However, the more she talks and acts in hypocritical and selfish manner, the more she brings her family and herself near to death.

The grandmother's four prominent character traits: lordliness, talkativeness, selfishness, and hypocrisy are revealed under the light of pragmatic analysis by examining the level of formality and politeness she uses in particular conversational situations. In other words, the interesting complicated personality of the grandmother and also how the characterization of the grandmother develops during the story can be inferred from her changing conversational behavior: she skillful and flexibly manipulates the language - support or attack face - in different contexts in pursuit of her goals, and deviates from her usual pattern of conversational behavior at the end of the play, where she appears more indirect and polite.

\section{Literature Review}

Different linguists present distinct definitions around the term 'politeness'. Among them, the most influential politeness theories are those of Goffman (1967), Leech (1983), Brown and Levinson (1987), and they will be reviewed as follows.

In social interaction, participants resort to a wide range of conversational strategies to maintain, support, or threat face. According to Goffman's dramaturgical framework (1967), the concept of face is like a mask that can change depending on the interlocutors and the situational context in order to reinforce social solidarity. Therefore, in daily conversations, people try their best to manipulate their messages by minimizing or avoiding conflict to maintain each other's faces.

In 1987, Brown and Levinson base their definition of politeness on the concept of face of Goffman (1967). In their view, face consists of two related components: positive face - the desire to obtain approval - and negative face - the desire to be unconstrained. In any social interaction, people are constantly strive to balance the two tendencies, namely attaining reputation and approval, exercising control, and - conversely - meeting others' expectations, creating intimacy. However, it is inevitable that our actions often inherently damage the other person's face. For example, criticism threatens positive face, and imperative commands threaten negative face. We call these acts are Face Threatening Acts (FTAs). Although many scholars acknowledge the universal presence of 'face', some have raised doubt about its application across diverse communities and cultures (Suleiman 2004: 55), the role of the interlocutors, and the 'conceptual bias' issue (Matsumoto 1988; Mao 1994; O'Driscoll 1996; Spencer-Oatey 2002; Watts, Ide \& Ehlich 2005).

There are a number of factors affecting weightiness of an FTA such as the relationship between interlocutors and the degree of imposition of the act to be performed. For instance, it is easier for me to borrow money from my best friend than a new acquaintance since I am closer to my best friend I have known for ages than someone I am getting to know, but I do not know he or she well (social distance). Also, if I had a choice for my birthday present by my friend, asking for a book would be less face threatening than asking for a car. In order to minimize the possibility of threaten to the other person's face, the speakers may adopt certain politeness strategies. The question about which appropriate politeness strategy is employed would depend on one's assessment of how face threatening a particular act is going to be (Culpeper 1998: 85). For the limit of space, this study does not attempt to go deeper into politeness strategies.

Whereas, politeness in Leech's view (1983: 19) is the means to show awareness of another person's face which 'can be measured in terms of the degree of effort put into the avoidance of a conflict situation'. Leech also introduces six main maxims to form the Politeness Principle which runs as follows:

Minimize (all things being equal) the expression of impolite beliefs; Maximize (all things being equal) the expression of polite beliefs. 
1. The Tact maxim: Minimize the expression of beliefs which imply cost to other; maximize the expression of beliefs which imply benefit to other.

2. The Generous maxim: Minimize the expression of benefit to self; maximize the expression of cost to self.

3. The Approbation maxim: Minimize the expression of beliefs which express dispraise of other; maximize the expression of beliefs which express approval of other.

4. The Modesty maxim: Minimize the expression of praise of self; maximize the expression of dispraise of self.

5. The Agreement maxim: Minimize the expression of disagreement between self and other; maximize the expression of agreement between self and other.

6. The Sympathy maxim: Minimize antipathy between self and other; maximize sympathy between self and other.

(Leech 1983: 138)

This set of maxims is the statements of norms for the participants to follow, but it does not have an absolute guidance because the conversational situations are very diverse. Applying any kind of maxim for all conversational situations can lead to or violate self-respect or violate the honor as well as equal treatment to others (Ho 1996). Therefore, we should be flexible and skillful in manipulating any kind of maxim in particular contexts. In the same vein, Lakoff (1973) and Gu (1990) introduce a conversational maxim approach - a rich explanatory source for cross-cultural pragmatic studies (Spencer-Oatey \& Jiang 2003). Accordingly, Fraser and Nolan (1981) and Fraser (1990) associate politeness with the fulfillment of conversational rights and obligations and call it a conversational contract. Watts (1989) links all three elements: face needs, conversational maxims and conversational rights and obligations, advocating that they are complimentary. Then Watts (2003) and Locher (2004) consider politeness appropriate but marked behavior (Abbas \& Suleiman 2014).

Even though different linguists approach the topic 'politeness' differently, it seems that all share their similar view when advocate that politeness is associated with the conflict avoidance and smooth communication in relation to socioculturally specific norms of linguistic behaviour (Blum-Kulka 1990; Kitamura 2000; Bharuthram 2003; Spencer-Oatey 2005; Hei 2008; Al-Hindawi \& Alkhazaali 2016).

There have been many attempts since the early 2000s to address shortcomings and extend politeness model of Brown and Levinson (1987) by introducing additional rules/ maxims/ principles (Terkourafi, 2005: 240) or by calling for a shift in how politeness is theorized in the field (Culpeper 1996; Watts 2003; Locher 2006; Haugh 2007). Specifically, Culpeper (1996) has introduced a model of 'impoliteness' for providing more sufficient explanation of some instances of speech and Spencer-Oatey (2002) has proposed 'rapport management'. Despite the considerable amount of criticisms, over the years Brown and Levinson's theory of politeness (1987) still retain its status for inspiration and immense influence (Harris 2001; Terkourafi 2005; Ermida 2006; Abbas 2013; inter alia) and its contribution to the development of today's research on politeness and impoliteness language phenomena as the continuum of social interaction (Culpeper 1998; Watts et all. 2005; Rudanko 2006) is undeniable (Luu 2011: 382).

Not only does Brown and Levinson's theory of politeness (1987) provide a theoretical and analytical tool for daily conversation but also for analyzing fictional character's personality traits via verbal interactions. In the last four decades, there are a number of studies that have drawn from different pragmatic theories to examine literary works (Leech 1992; Rozik 1996b; Yang 2007; Rossen-Knill 2011). One of the prevalent and powerful pragmatic theories applied in analyzing literary texts is the theory of politeness and among many theories, the work of Brown and Levinson (1987) is most often used. Indeed, the fact that frameworks of linguistic politeness can be used to form judgments about characters in literature is successfully manifested in a number of studies in relation to the notion of face (Buck \& Austin 1995; Buck 1997; Chikogu 2009), politeness strategies (Simpson 1989; Rossen-Knill 1995; Abbas 2013), politeness principle (Bennison 1998; Chun 2010) and others.

As can be seen from these studies, politeness in conversation is really crucial in characterization since it elaborately describes how participants, in relation to others, manipulate the language to pursuit their particular goals. The relationship between pragmatics and literature has become the researcher's motivation for undertaking a similar study in order to explore how pragmatic elements in general and politeness in particular can assist in literary interpretation.

\section{Methodology}

This study examines the notion of face and politeness aspects in the conversations of the story $A$ good man is hard to find. This research employs the qualitative research which is done by collecting the data in the form of utterances, classifying the data, analyzing the data chronologically by page on which they are written, and then drawing the conclusion.

It is applicable to analyze the pragmatic theories in short stories, especially the works mostly composed of conversations like $A$ good man is hard to find. The pragmatic theories of the notion of face and politeness are applied to the analysis of the conversations to enhance the understanding and interpretation of the prominent character traits and to prove the effective power of such kind of pragmatic analysis in the study of short stories.

In order to answer the question how four prominent character traits are inferable from the grandmother's conversational behavior, the researcher examines the grandmother's behavior from the light of pragmatic analysis, in terms of the meaning of her utterances in particular situation. The implications of the grandmother's statements will be examined by 
referring to three pragmatic frameworks: Goffman's concept of face (1967), Brown and Levinson's politeness phenomenon (1987), and Leech's Politeness Principle (1983).

\section{Discussion}

The story begins with the conversation between the grandmother and her son, Bailey at home. In the very beginning, the grandmother is not polite when she attacks the face of her family members one by one. To be more specific, the grandmother's first utterances to her son: 'Now look here, Bailey', 'see here, read this', 'Here this fellow that calls himself The Misfit is aloose from the Federal Pen and headed toward Florida and you read here what it says he did to these people. Just you read it' threatens negative face (the want to be impeded) in causing inconvenience, directly forcing Bailey to read the newspaper about The Misfit by using many direct orders 'look here', 'see here', 'read this', 'just you read it'. Her next utterances 'I wouldn't take my children in any direction with a criminal like that aloose in it. I couldn't answer to my conscience if I did' could be interpreted as criticism, but the hedge 'I wouldn't', 'I couldn't' and the use of second condition sentences reduce a little bit the force of the speaker's criticism. The utterances shows the grandmother's great concern for her family, especially her grandchildren who are only children and should not be involved in such a horrifying and deadly situation, and expresses her kindness, but simultaneously shows her face wants. She desires other people to respect her for her thoughtfulness to the well-being of her family members and her power the oldest person in the family; it's only her to have the right to make orders, and the others must obey her.

However, Bailey gives her no response or acknowledges to her existence and continues to do his own business, burying his head over the sports section of the Journal. While the grandmother tries to turn to her daughter-in-law for help and advocates that visiting different places might be more educationally beneficial to the children, her daughter-in-law takes no notice of her words, either - 'The children have been to Florida before. You all ought to take them somewhere else for a change so they would see different parts of the world and be broad. They never have been to east Tennessee.' There is no co-operative endeavor to enable conversation to proceed. No matter how hard the grandmother tries to persuade and reason with her son and daughter-in-law by using every means she has such as touch, raising sound, demanding gesture and the modal verbs 'ought to', 'would', silence is the only answer.

Nevertheless, the children's responses are different. The eight-year-old boy, John Wesley, says to her, 'If you don't want to go to Florida, why dontcha stay at home?'. Then the little girl, June Star responds to John Wesley's rude remark, makes her comment without even directly facing and talking to the grandmother: 'She wouldn't stay at home to be queen for a day. She wouldn't stay at home for a million bucks,' and adds another comment, 'Afraid she'd miss something. She has to go everywhere we go'. The grandchildren's criticism threatens the grandmother's positive face (the want to be approved of) when they support their parents' opinion to take a trip to Florida, and in a childish manner they dissuade her from going with them, laughing at her dependence on them. John Wesley's and June Star's remarks make readers surprised since they expect politer behavior of grandchildren to their grandmother. In order to minimize the threat to her face posed by her grand-daughter, the grandmother in the same childish manner threatens June Star's positive face by warning of not curling her hair any more in the future: 'All right, Miss. Just re-member that the next time you want me to curl your hair.' Compared to the silent response from her son and daughter-in-law, her dialogue with her grandchildren is full of sound but irony. In fact, the parents show no intervention to reprimand their children's ill manners, and this can be considered as the implicit approval of their children's impudence. Tired of arguing with the grandmother, the parents let the children fulfill the duty for them.

From the conversations above, the readers know that the grandmother is not well-respected or listened to by any family members or her positive face is not accepted at home. Therefore, the readers are urged to seek answers for the question why the old as the grandmother gains little respect. As can be seen from the language usage, there is a disharmony within the family members: the grandmother's face wants are not accepted since she receives no reply and sometimes is completely ignored by her family members. According to Culpeper (1998: 86), the conflict in interaction and the discontent among characters help readers to see plot and character developments. The grandmother has personal reason without disclosure for visiting her hometown where she still has connections there, so she tries everything in her power to get the family to go to Tennessee. She skillfully manages to get what she wants by only warning the family about the possible danger of the trip to Florida. Her son and her daughter-in-law, however, are so familiar with her conversational strategies that they choose to say nothing to save her positive face, but their children impudently damage her face by replying without respect.

Although the family takes no consideration to her advice and commences the trip to Florida the next day, the grandmother is stylish and ready in the car in the early morning. In the car, the grandmother continues to speak much more than other family members: warns Bailey not to drive too fast, educates the children on the pride of their native state, and reasons that the children were more respectful in her time - 'If I were a little boy, I wouldn't talk about my native state that way. Tennessee has the mountains and Georgia has the hills. In my time, children were more respectful of their native states and their parents and everything else. People did right then.' She uses the same conversational strategy like they were at home to ask the children to behave correctly by employing the second conditional sentence and the past tense.

The appearance of a small black child standing in the door of a shack 'Oh look at the cute little pickaninny!' brings back the bygone South with the traditional manners and values of descent and elegance. It is the good chance for the grandmother to save her face or be proud of her lineage and manners by referring to this child as a 'pickaninny'. Right away, June Star shows her surprise at the black boy without pants on. This is another opportunity for the grandmother to lecture her grandchildren, 'Little niggers in the country don't have things like we do.' June Star represents the new 
Southern generation, not familiar with the concept of class and race whereas the grandmother is a symbol of the old South, who is pleased with the white predominance over the Negroes. It should be noted that in this case, the manipulation of her offensive words 'pickaninny' and 'niggers' on the one hand attacks the black boy's face on his poverty and inferior heritage, and on the other hand implicates the desire of her positive face. However, just a few second ago, she preaches at John Wesley's contemptuous remarks on the poverty of his Georgia and her hometown Tennessee. Her conversational behavior here invites interpretation. A strong possible explanation is that she is hypocritical: always tries to show that she respects other people on the surface to save their face, but in fact she cleverly praises herself by objectification of others.

The grandmother's face wants are not satisfied at home, and now she believes to totally gain her lost face on the trip. She plays the teacher role of many different subjects to teach her grandchildren about history, geography, race, moral, culture, class status. The grandmother assumes that she is better than other people who are not like her - a white lady with the privilege that the Negroes never have, and she always remind others about this. Although on the road the grandmother speaks much more than other members in her family and seems to control the conversations, no real communication occurs because her son and her daughter-in-law's contribution to dialogue is zero. This signal is again an objection to her positive face.

On their way to Florida, the family stops at the Red Sam's for lunch. Waiting for their order, the mother plays The Tennessee Waltz on the nickelodeon which makes the grandmother want to dance, and she invites Bailey to dance, but he continues to keep silent and rejects her suggestion by glaring at her. Bailey Boy's respond threatens her positive face for not accepting her offer. When Red Sam's wife wants to have small talk with June Star 'Would you like to come be my little girl?', June Star replies 'No I certainly wouldn't,' 'I wouldn't live in a broken-down place like this for a million bucks!'. Immediately, the grandmother rebukes June Star for her rudeness 'Arn't you ashamed?' and concurrently shows her politeness to Red Sam's wife by noticing her feelings and exploiting the tact maxim - minimize the threat posed by her granddaughter. Acknowledging that Red Sam's wife is a stranger (in term of social distance), the grandmother tries to save her face to reinforce social solidarity. It seems that in the Bailey family, only the grandmother knows how to behave correctly in social interaction. Then Red Sammy and the grandmother lively discuss how people are different now and how a good man is hard to find. One more time, the grandmother shows her superficiality in judging others for not being as she is 'People are certainly not nice like they used to be,' and praising Red Sammy for being a good man 'Because you're a good man!' She employs the approbation maxim (maximize the approval of other) to compliment Red Sammy, but the question here is her sincerity. The fact that the grandmother's changing conversational behavior is easily noticed in her capability of producing context-sensitive behavior to obtain her aims.

As can be observed, another possible reason for the Bailey family's manipulation of FTAs to the grandmother is the generation gap. The conventions in the grandmother's time such as morals and good manners turn out to be out of date now and therefore no longer attract any attention from her family members. Indeed, neither the righteousness nor a good man could be easily found among the present youth since material values dominate human behavior. However, in their conversation about the customs of the South, the grandmother, Red Sam, and his wife, who seem to belong to the bygone days, share their common values of gentility without really thinking about the actual meaning of a good person. It is the lack of communication to love, sympathy, and understanding that leads to the massacre of the whole family at the end.

The family gets back on the road for their trip after lunch, and the grandmother longs to visit the old plantation house than ever. Knowing that her son would not fulfill her wish, she makes up story about the hidden treasure in that old mansion. Fortunately, this time her conversational strategy works as the children begin to yell, scream and kick in order to force their father to stop the car. Taking the advantage of the situation, the grandmother adds in her soft voice 'It would be very educational for them'. Although Bailey at last complies with the grandmother's will, he is not happy with this and poses an imperative command 'All right, but get this: this is the only time we're going to stop for anything like this. This is the one and only time' which is particularly face threatening to the grandmother. It should also be noted that this is the first time in the story he speaks so far.

The new generation like June Star and Wesley are no longer interested in the gentility, glorious past, and vanishing value system which the grandmother always expresses her seriousness; instead, they only care about monetary and modern commercialized cultural system, and their desire to visit the old mansion is because of its hidden treasure only. Her efforts in showing and educating the grandchildren about glorious past turn out to denounce her selfishness. She does all kinds of tricks with the only purpose of attaining what she wants: even lying about the hidden treasure to evoke curiosity in her grandchildren.

At the very moment that the grandmother becomes aware of her mistake: that house was in Tennessee, it is her panic that causes the car to turn over and the confrontation with The Misfit and his henchmen. In her encounter with The Misfit, the grandmother's superficial beliefs in the old Southern mannerisms now confront a challenge. The Misfit is a prison escapee who looks polite, smart, and well-educated. In his conversation with the grandmother, The Misfit tends to save her face, which she wants so much. His conversational behavior towards the grandmother is completely different from what she receives from her family members. In other words, he has the manners that all parents would want for their children. The Misfit politely greets the family first 'Good afternoon. I see you all had you a little spill', and continuously supports the grandmother's positive face in addressing her 'lady', 'ma'am'- the highest level of formality. After hearing many noises from the Bailey's children, The Misfit indirectly requests the mother for making her children to sit down: 'Lady, would you mind calling them children to sit down by you? Children make me nervous'. Knowing that his request for permission to discipline her children threatens the negative face of the mother, he raises a question about whether the 
mother minds, not whether he can do it. The possibility that The Misfit and his henchmen might be parents of the children is not true by the fact that it is set in a hypothetical context with the use of the modal conditional 'would'. Interestingly, The Misfit, an outsider and the first person, resets order in the Bailey family on the behalf of the children's parents.

The grandmother, unluckily, blurts out that she recognizes The Misfit, making her son rage. When Bailey says something rude to her, The Misfit apologizes for Bailey, saying 'Lady, don't you get upset. Sometimes a man says things he don't mean'. His utterance supports her positive face in expressing concern for her feelings and her need - comfort since she begins to cry. He persuades her that the bad words Bailey said to her do not show his true feelings. The hedging non-factive verbal construction 'don't you get upset' and the adverb 'sometimes' remove the threat of face wants from the grandmother. One more time, The Misfit helps her with domestic chores in resolving her family conflicts. His behavior really comforts her, and she mistakes his gentleness as a sign of his Southern cultural norms which could treat her, a lady, differently. For that reason, she quickly makes every effort to let her free/ tries to persuade The Misfit to let her free. Her utterance 'You wouldn't shoot a lady, would you?' is a combination of hope and interrogation: the grandmother states what she hopes to be true and invites The Misfit to confirm it. Afraid of her FTA threatens the Misfit's negative face, the grandmother indirectly requests that he should not kill her, a lady. The hedge 'wouldn't' reduces the force of her request and her indirect question with the use of tag question 'would you?' expects confirmation from The Misfit. The readers, at this moment, can see that she is full of herself when paying no concern for the wellbeing of anyone else in her family except herself.

Instead of confirming as required, Misfit replies in his turn by not giving a straight answer 'I would hate to have to'. His reply is totally neutral: he is evasive. If The Misfit is sure about the answer, he just simply replies 'yes' or 'no', the shortest and most uncomplicated reply. To be more specific, 'I wouldn't' would have entailed the actual reply, but 'I would hate to have to' does not entail 'I wouldn't'. The grandmother notices that The Misfit is apparently violating the tact maxim - minimizing cost to other - and deduces that he would hate to have to kill her and he might have to do what he hates: killing her. Through his reply, the conditions of success for the grandmother's wish are unfulfilled; her demand is ignored and her life is threatened.

Not getting the expected confirmation she wants, she is full of fear, uttering these words to persuade him: 'Listen, I know you you're a good man. You don't look a bit like you have common blood. I know you must come from nice people!' The grandmother shows her quick and clever adaptation to new situations in her dialogue with Red Sammy and now with The Misfit. She employs the approbation maxim, praising them as good men. However, the question is her sincerity. Again, the readers can easily recognize that the grandmother can produce context sensitive behavior by observing power, social distance and feelings (face wants) of the participants to pursue her goals in a particular context. Judging from appearance such as politeness and good manners, the grandmother easily tells the interlocutor - in face value - that he is a good man. However, The Misfit knows himself better than anyone else, so he does not easily accept any superficial judgment like this. Recognizing the strategy the grandmother is using, The Misfit does not let himself fall in her trap. The Misfit's conversational behavior is suddenly different from what he showed in previous utterances. He directly refuses the grandmother's praise 'Nome, I ain't a good man'. By giving a negative statement which infringes the agreement maxim (minimize the expression of disagreement between self and other), The Misfit threatens the grandmother's positive face. This is the first time in the story he is not polite, which also implies that he does not want to release her. The Misfit's fluctuating politeness behavior reflects his awareness of his great power: he knows that he is not obliged to be polite as he has the right to kill anyone.

Realizing the topic about his excellent breed does not work, the grandmother tries to initiate a new topic by referring to the prayer 'Do you every pray?' She upholds politeness strategy: asking about the reason why he was sent to the prison in order to create a close relationship with him. Again, The Misfit is uncooperative by giving a lengthy and inadequate explanation. His reason is very vague and clearly provides too much information. The Misfit is at once aware of her intention in the sudden topic change, so his complicated replies implicate not only his loss of interest in the topic but also his superiority of topic control.

'Turn to the right, it was a wall. Turn to the left, it was a wall. Look up it was a ceiling, look down it was a floor. I forget what I done, lady. I set there and set there, trying to remember what it was I done and I ain't recalled it to this day. Once in a while, I would think it was coming to me, but it never come.'

Listening to his story, the grandmother pretends to sympathize with him 'Maybe they put you in by mistake'. The hedge 'maybe' reduces the truth of the fact and 'they put you in by mistake' is an oblique way of expressing the fact. Her sympathetic response to The Misfit's explanations upholds the tact maxim by saying that maybe he was put into prison by mistake. However, The Misfit considers himself as a sacrifice to the social and political rules and for such an escaped convict, there is no social justice - he would rather set up his own rules. He trusts no one and is gratified with taking no help (Tsai, 2004: 86).

'If you would pray,' the old lady said, 'Jesus would help you.'

'That's right,' The Misfit said.

'Well then, why don't you pray?' she asked trembling with delight suddenly.

'I don't want no help,' he said. 'I'm doing all right by myself.' 
Happy with the cooperative behavior of The Misfit when he shows his first agreement 'That's right' for her statement, she tries to take advantage of this very last chance, religion, to convert him. She indirectly performs the request by asking the question why The Misfit does not pray and the hedge 'well then' to minimize the imposition of her request. The fact that The Misfit is a killer makes her adopts a much more polite manner not to risk threatening his negative face. The expression "well then" also implies that maybe she does not believe that prayer or Jesus would help, but she just pretends that. However, The Misfit tells her that he wants no help, breaking her last hope into pieces.

Next The Misfit challenges the grandmother's religious conviction and concurrently demands her approval 'Does it seem right to you, lady, that one is punished a heap and another ain't punished at all?'. In fact, The Misfit's utterance is loaded a question which requires no answer, and really function as threat. In other words, he does not want to maintain social harmony with her: his FTA threatens her negative face in forcing her to answer an extremely tough question. Understanding this, the grandmother abandons rules of cooperative principle by uttering one word 'Jesus!' Not knowing what to say, she does not reply his question at all, but merely shows that she has understood what has been said. Her answer deliberately breaks the maxim of agreement. She is avoiding answer his question which might threaten her life.

The grandmother reiterates the compliment and the request in her following turn: 'You've got good blood! I know you wouldn't shoot a lady! I know you come from nice people! Pray! Jesus, you ought not to shoot a lady. I'll give you all the money I've got!' The possibility that he might release her is further distanced - and thus made more indirect - by the fact that it is set in a hypothetical sentence indicated by the modal conditional 'wouldn't' and 'ought not to'. Then the grandmother also provides the reasons why he would not shoot her: she is a lady and she will give him all her money. In saying this, the grandmother is offering to do him a suggestion which she thinks that he might need (face wants).

However, The Misfit cleverly rejects her request and offer by saying a statement with a figurative meaning 'Lady, there never was a body that give the undertaker a tip.' This time, his answer is more explicit than the previous reply 'I would hate to have to' and that she soon becomes a body. The grandmother's conversational strategy is failed again. For The Misfit, there is no Jesus, miracle, salvation, nor hope: he trusts nobody, except himself. No one or nothing can stop what he wants to do: killing people.

Now the grandmother feels her politeness strategy get in tuck. 'Maybe He didn't raise the dead,' the old lady mumbled. Here the grandmother does not follow Leech's maxim of agreement to save The Misfit face because if she follows it, she accepts her death and should stop persuading The Misfit not to kill her. She does not dare to speak out loud, but 'mumble' the words to show her discontent which she thinks somewhat can save her life. The hedge 'maybe' allows the grandmother to personalize and mitigate the force of what she says because she has no power to sound definite and authoritative, is not fully understand Christianity, or is searching for the right words. In any cases, she is sensitive to face for the purposes of self-protection and not wanting to put The Misfit in a face-threatening situation.

The Misfit continues monologue about his doubt in religion and himself: 'I wasn't there so I can't say He didn't. I wish I had of been there. It ain't right I wasn't there because if I had been there I would of known. Listen Lady, if I had of been there I would of known and I wouldn't be like I am now.' He cannot believe in Jesus's miracle in his raising of the dead as he cannot 'see' by his eyes. He is confused between the mysterious truth and the fact based on what his eyes can perceive. Trust in Jesus, or in religion, however, is never based on vision of face value, but from deep spiritual understanding and faith. The Misfit completely controls the right to talk by replying without a full answer, giving vague statements, and asking questions to which he already knows the answers. Each time the grandmother asks a question, the Misfit responds to it by giving too much information with the attempts to establish his control.

The Misfit and the grandmother are alike: they trust no one and both judge from appearance. In the trembling moment, the grandmother is enlightened to see through The Misfit so as to understand and sympathize his complicated life. She sees his face twisted close to her own as if he were going to cry and she murmurs, 'Why you're one of my babies. You're one of my children!' She expresses her intimacy and sympathy for his personal issues by referring to him as one of her 'children' and reaching out to touch his shoulder. Indeed, she can 'see' more deeply through his harsh and bitter words that he needs the consolation and with the maternal instinct, she stretches out her hands for the purpose of embracing. Her manipulation of the sympathy maxim (maximize sympathy between self and other) in words indicates that she sensitively notices The Misfit's conditions and conveys her attention towards him by offering a touch. It can be inferred that she saves his positive face by understanding his needs and fulfilling his wants. Without understanding her gesture, an action of the recognition of humanity and the sign of love, he rejects her compassionate by shooting her three times through the chest. The Misfit believes that the upcoming death forces the shallow selfish grandmother to admit her imperfection 'She would of been a good woman, if it had been somebody there to shoot her every minute of her life', so he lets her die as a 'good' woman. In fact, the grandmother's touch of compassion in crucial moment - the transformation chance for The Misfit - shocks him that he is forced to kill her to stop contamination from a manipulative hypocritical person with doubtful faith and shallow judgments.

As can be observed in her conversations with The Misfit, the grandmother is generally careful to be polite or not to violate the Politeness Principle, but in her dialogues with the family members at home, she abandons this attitude. Now her conversational behavior is characterized by her politeness and face-saving strategies. She is no longer a domineering old woman who is in her regular use of directives ('Now look here', 'see here', 'read this') demanding the attention, obedience and acceptance of her family members. Instead, she always tries to create intimacy with The Misfit by praising and sympathizing with him, and her contribution to the conversations with him is restricted than to any other dialogues with her family member although she initiates the topics. The grandmother's fluctuating politeness behavior reflects her awareness of her losing power: her life is in the hand of the interlocutor. In contrast, The Misfit tends to 
establish the social distance with the grandmother by using the highest scale of politeness in addressing her with the title of respect 'Lady' and support her face on surface.

The Misfit controls the conversations by making the grandmother stop talking about a topic to change to another one (a good man $\rightarrow$ prayer $\rightarrow$ mighty of Jesus) and helping her to realize she is not better than anyone else. The grandmother knows that The Misfit impedes her contribution and thus damaging her negative face despite his formal language and polite manners. So far, then, the conversation has taken the form of a struggle for control, where The Misfit has finally won, and where the grandmother's politeness strategies are never successful. The Misfit's refusal to all the grandmother's suggestions threatens her face. The grandmother uses many hedges, hesitations, and repetitions which indicates her lack of power. It seems that the grandmother is a good conversationalist when she makes use of skills for topic management and conversational routines to initiate and develop conversation on a wide range of topics while observing the notion of face, politeness phenomenon and politeness principle to express and interpret other's utterances. However, her conversational strategies are failed when she confronts with The Misfit's religious nihilism. The more she tries to create intimacy with the Misfit by approving and accepting him in order to save her own life, the more she annoys him to shoot her dead.

In brief, like other studies (Simpson (1989), Rossen-Knill (1995), Buck (1997), Chikogu (2009), Chun (2010), Abbas (2013) and others), the findings of this study prove that pragmatic analysis can enhance the interpretation of literary works.

\section{Conclusion}

This paper has demonstrated that politeness theories can provide significant insights into the grandmother's character in Flannery O'Connor's A Good Man Is Hard to Find. In other words, the grandmother's four prominent character traits are inferable from her changing conversational behavior through her employment of politeness theories namely the notion of face, politeness phenomenon, and politeness principle in conversational situations. In this short story, politeness is crucial to the construction of character since the politeness level used by a character show the shift of character. Therefore, development in character which gained from politeness analysis suggests the application of other pragmatic theories as the framework in analysing characterization in literary works to capture the richness of character.

\section{References}

Abbas, N. F. \& Suleiman, R. (2011). Politeness: Characterization and Literary Discourse. Language in India, 11 (11), 569-586.

Abbas, N. F. (2013). Strategic Politeness in Montgomery's Anne of Green Gables. World Journal of English Language, $3(1), 1-10$.

Abbas, N. F. \& Suleiman, R. (2014). Politeness in literary works: an overview. In S. Kaur \& S. Abdul Manan (Eds.), Contemporary Perspectives in English Language Studies: Linguistics and Literature. Penang: Universiti Sains Malaysia Press.

Al-Hindawi, F. H. \& Alkhazaali, M. A. (2016). A Critique of Politeness Theories. Theory \& Practice in Language Studies, 6(8), 1537-1545.

Bennison, N. (1998). Accessing character through conversation: Tom Stoppard's Professional Foul. In Culpeper, J., Short, M., \& Verdonk, P. (Eds.), Exploring the Language of Drama: From Text to Context. London: Routledge, pp. 6782 .

Bharuthram, S. (2003). Politeness Phenomena in the Hindu Sector of the South African Indian English Speaking Community. Journal of Pragmatics, 35, 1523-1544.

Blum-Kulka, S. (1990). You Don't Touch Lettuce with Your Finger: Parental Politeness in Family Discourse. Journal of Pragmatics, 14, 259-288.

Brown, P. \& Levinson, S.C. (1987). Politeness: Some Universals in Language Usage. Cambridge: Cambridge University Press.

Buck, R. A. \& Austin, T. R. (1995). Dialogue and power in E. D. Forster's Howards End. In P. Verdonk \& J. J. Weber (Eds.), Twentieth Century Fiction: From Text to Context. London: Routledge, pp. 63-77.

Buck, R. A. (1997). Towards an extended theory of face action: Analyzing dialogue in E. M. Forster's A Passage to India. Journal of Pragmatics, 27, 83-106.

Chikogu, R. N. (2009). A Pragmatic study of the linguistic concept of politeness and change in social relations of power in Wole Soyinka's The Beautification of Area Boy. English Text Construction, 2(1), 70-90.

Chun, L. \& Yun, Z. (2010). Apology strategies between social unequals in The Dream of the Red Chamber. Chinese Language and Discourse, 1(2), 264-287.

Culpeper, J. (1996). Towards an anatomy of impoliteness. Journal of Pragmatics, 25, 349-367.

Culpeper, J., Short, M., \& Verdonk, P. (1998). Exploring the language of drama: From text to context. London; New York: Routledge.

Culpeper, J. (2001). Language and Characterization: People in Plays and Other Texts. London: Longman. 
Ermida, I. (2006). Linguistic Mechanism of Power in Nineteen Eighty-Four: Applying Politeness Theory to Orwell's World. Journal of Pragmatics, 38, 842-862.

Goffman, E. (1967). Interaction Ritual: Essays on Face-To-Face Behavior. Garden City, New York.

Harris, S. (2001). Being politically impolite: extending politeness theory to adversarial political discourse. Discourse \& Society, 12 (4), 451-472.

Haugh, Michael (2007). The discursive challenge to politeness research: An interactional alternative. Journal of Pragmatics, 3, 295 - 317.

Hei, K. C. (2008). Strategies of politeness used by grandparents in intergenerational talks. In M. K. David \& K. K. Cheng (Eds.), Politeness in Malaysian Family Talk (120-168). Serdang: Penerbit Universiti Putra Malaysia.

Ho, L. (1996). Quy luật ngôn ngũ, Quyển II: Tính quy luật của co chế ngôn giao [Rules of Language, Book No.2: Regularity of speech communication mechanism], Social Science Publisher.

Kitamura, N. (2000). Adapting Brown and Levinson's politeness theory to the analysis of casual conversation. In Proceedings of ALS2k: The 2000 Conference of the Australian Linguistic Society.

Leech, G.N. (1983). Principles of Pragmatics. London: Longman

Leech, G.N. (1992). Pragmatic Principles in Shaw's You Never Can Tell. In M. Toolan (Ed.), Language, Text and Context: Essays in Stylistics. London: Routledge, pp. 259-280.

Locher, M. (2006). Polite behaviour within relational work: the discursive approach to politeness. Multilingua, 25 (3), $249-267$.

Luu, T. T. (2011). Exploring Pragmatics: A coursebook. Social Sciences Publishing House.

Mao, L. R. (1994). Beyond politeness theory: 'face' revisited and renewed. Journal of Pragmatics 21, 451-486.

Matsumoto, Y. (1988). Reexamination of the universality of face: politeness phenomena in Japanese. Journal of Pragmatics 12, 403-426.

O'Connor, F. (1992). A Good Man Is Hard to Find and Other Stories. New York: Harcourt, pp. 1-23.

O'Driscoll, J. (1996). About face: A defense and elaboration on universal dualism. Journal of Pragmatics, 25(1), 1-32.

Rozik, E. (1996b). Multiple metaphorical characterization in Le Roi se meurt. Nottingham French Studies, 35(1), 120131.

Rossen-Knill, D. F. (1995). Towards a Pragmatics of Dialogue in Fiction. Unpublished Thesis: University of Minnesota.

Rossen-Knill, D. F. (2011). How dialogue creates opposite characters: An analysis of Arthur \& George. Language and Literature, 20, 43-58.

Rudanko, J. (2006). Aggravated Impoliteness and two types of speaker intention in an episode in Shakespeare's Timon of Athens. Journal of Pragmatics, 38, 829-841.

Simpson, P. (1989). Politeness Phenomena in Ionesco's The Lesson. In R. Carter and P. Simpson (Eds), Language, Discourse and Literature. London: Routledge, pp. 170-193.

Spencer-Oatey, H. (2002). Managing Rapport in Talk: Using rapport sensitive incidents to explore the motivational concerns underlying the management of relations. Journal of Pragmatics, 34(5), 529-545.

Spencer-Oatey, H. (2005). (Im)Politeness, face and perception of rapport: Unpackaging their bases and interrelationships. Journal of Politeness Research, 1(1), 95-120.

Suleiman, R. R. (2004). Face considerations in Malay: An examination of offers and requests in Malay plays. Unpublished doctoral dissertation. University of Malaya, Malaysia.

Terkourafi, M. (2005). Beyond the micro-level in politeness research. Journal of Politeness Research, 1 (2), $237-262$.

Tsai, H. (2004). Violence as the Road to Transformation: O'Connor's A Good Man is Hard to Find. NTU Studies in Language and Literature, 13, 59-98.

Watts, Richard J. (2003). Politeness. Cambridge: Cambridge University Press.

Watts, R., Ide, S. \& Ehlich, K. (Eds.) (2005). Politeness in language: Studies in its history, theory and practice (2 ed.). Berlin: Mouton de Gruyte.

Yang, L. (2007). A Pragmatic Analysis of the Conversations in The Killers. US-China Foreign Language, 5(3), 8. 